J. Clin. Chem. Clin. Biochem.

Vol. 21, 1983, pp. 39-43

\title{
Competitive Enzyme Immunoassay for Apolipoprotein A-II
}

\author{
By B. Dufaux, K. Ilsemann and G. Assmann
}

Zentrallaboratorium der Medizinischen Einrichtungen der Westfälischen Wilhelms-Universität Münster und Institut für Arterioskleroseforschung an der Universität Münster und Institut für Kreislaufforschung und Sportmedizin der Deutschen Sporthochschule Köln

(Received May 26/August 10, 1982)

Summary: A competitive enzyme immunoassay for apolipoprotein A-II was developed. Microtitre plates were used as a solid phase and coated with anti-apolipoprotein A-II antibodies. Purified apolipoprotein A-II, labelled with horseradish peroxidase was used as competing ligand.

The assay was examined with respect to the optimal amounts of specific anti-apolipoprotein A-II antibodies and apolipoprotein A-II-enzyme conjugate. The displacement curves showed a good parallelism between serum and purified apolipoprotein A-II. Delipidation of serum did not affect the content of apolipoprotein A-II. Cross-reactivity with apolipoprotein A-I was minimal. The intra- and inter-assay coefficients of variation in the medium range were 9.0 and $11.8 \%$ respectively. The assay might be well-suited for clinical routine.

\section{Kompetitiver Enzymimmunoassay für Apolipoprotein A-II}

Zusammenfassung: Es wurde ein kompetitiver Enzymimmunoassay für Apolipoprotein A-II entwickelt. Für die feste Phase wurden Mikrotiterplatten benutzt, die mit Anti-Apolipoprotein A-II Antikörpern beschichtet waren. Als konkurrierendes Bindungsreagenz wurde gereinigtes Apolipoprotein A-II, markiert mit Meerrettich-Peroxidase, eingesetzt. Der Assay wurde hinsichtlich der optimalen Menge des spezifischen Anti-Apolipoprotein A-II Antikörpers und des Apolipoprotein A-II Konjugates überprüft. Die Verdrängungskurven zeigten eine gute Parallelität zwischen Gesamtserum und gereinigtem Apolipoprotein A-II.

Eine Delipidierung des Serums beeinflußte die Konzentration des Apolipoprotein A-II nicht. Die Kreuzreaktion mit Apolipoprotein A-I war geringfügig. Die Variationskoeffizienten betrugen im mittleren Meßbereich in der Reihe 9,0\% und von Tag zu Tag 11,8\%. Dịe Methode dürfte für Routine-Bestimmungen von Apolipoprotein A-II geeignet sein.

\section{Introduction}

Epidemiological results showing a négative correlation between plasma high density lipoprotein (HDL) cholesterol levels and the incidence of coronary heart disease have caused an increased awareness of the value of HDL determinations in the evaluation of the individual coronary risk. This has led in recent years to the development of immunoassays for the apolipoproteins of HDL. An especially large number of studies has been devoted to the quantification of the apolipoproteins A-I and A-II which together account for 90 percent of the total protein content of HDL.

A number of quantitative assays such as single radial immunodiffusion $(1,2,3)$, rocket immunoelectrophoresis (4) and radioimmunoassay (5-10) for apolipoprotein A-II have been described. Considering the considerable discordances between the reported normal apolipoprotein A-II values $(1-10)$, it appears that this apolipoprotein has been difficult to quantify. 
Here we report the development of an enzyme immunoassay for apolipoprotein A-II. The enzyme immunoassay technique shares with the radioimmunoassay several important advantages compared with single radial immundiffusion and rocket immunoelectrophoresis, such as sensitivity, the small amount of antiserum required, and the large number of samples which can be handled in each assay. Relative to the radioimmunoassay, the enzyme immunoassay benefits from low investment costs, stability of reagents and absence of biohazards associated with the handling of radioactive materials. It therefore seemed appropriate to try this technique for the estimation of apolipoprotein A-II concentrations in serum.

\section{Materials and Methods}

\section{Materials}

Horseradish peroxidàse (EC 1.11.1.7. Reinheitszahl ca. 3.0) was purchased from Boehringer Mannheim, FRG; bovine serum albumin, RIA grade from Sigma, Munich, FRG; Tween 20 from Serva, Heidelberg, FRG; $o$-phenylenediamine and hydrogen peroxide from Merck, Darmstadt, FRG; Sephacryl S 200 and S 300 from Pharmacia, Freiburg, FRG; DEAE-Trisacryl from LKB, Düsseldorf, FRG; Freund's adjuvant from Behringwerke Marburg, FRG).

The assays were performed in 96-well, round-bottomed microtitre plates M-124 B from Flow Laboratories, FRG.

All other reagents were analytical grade.

\section{Reagents}

Carbonate-hydrogencarbonate buffer:

$1.6 \mathrm{~g} / \mathrm{l}$ sodium carbonate and $2.95 \mathrm{~g} / \mathrm{l}$ sodium hydrogencarbonate pH 9.6. This buffer should be made up freshly every week.

Phosphate-buffered saline containing Tween:

$1.48 \mathrm{~g}$ of disodium hydrogen phosphate, $0.43 \mathrm{~g}$ of potassium dihydrogen phosphate, $8.77 \mathrm{~g}$ of sodium chloride and $0.5 \mathrm{ml}$ Tween 20 were dissolved in $800 \mathrm{ml}$ of distilled water. After adjustment of the $\mathrm{pH}$ to 7.2 , the solution was diluted to 11 with distilled water.

\section{Phosphate-citrate buffer:}

$8.52 \mathrm{~g}$ of disodium hydrogen phosphate and $5.25 \mathrm{~g}$ of citric acid were dissolved in $800 \mathrm{ml}$ of distilled water. After adjustment of the $\mathrm{pH}$ to 5.0 , the solution was diluted to 11 with distilled water.

\section{Chromogen solution:}

The substrate solution was made up immediately before use. $15 \mathrm{mg}$ of $o$-phenylenediamine were dissolved in $100 \mathrm{ml}$ of the above phosphate-citrate buffer and $40 \mu \mathrm{l}$ of hydrogen peroxide $(300 \mathrm{~g} / \mathrm{l})$
were added.

\section{Preparation of apolipoprotein A-II}

HDL $(1.063<\mathrm{d}<1.21 \mathrm{~kg} / \mathrm{l})$ was isolated by sequential ultracentrifugation from normolipaemic individual donors and was delipidated by ethanol-ether (volumes, $300 \mathrm{ml}+200 \mathrm{ml}$ ) at $-10^{\circ} \mathrm{C}(11)$.
The residue was finally dried under $\mathrm{N}_{2}$ and the delipidated $\mathrm{HDL}$ was fractionated by Sephacryl S 300 in $6 \mathrm{~mol} / 1$ urea, $0.05 \mathrm{~mol} / 1$ Tris- $\mathrm{HCl} \mathrm{pH}$ 8.6. The fractions corresponding to apolipoprotein A-II were further purified after lyophilisation by chromatography on DEAE-Trisacryl in $6 \mathrm{~mol} / \mathrm{l}$ urea employing a linear gradient (0.001 mol/1 Tris-HCl pH 8.6-0.02 mol/1 Tris- $\mathrm{HCl} \mathrm{pH} \mathrm{8.6).} \mathrm{Frac-}$ tions corresponding to apolipoprotein A-II were extensively dialyzed against $0.001 \mathrm{~mol} / 1 \mathrm{NH}_{4} \mathrm{HCO}_{3}$ and lyophilized. A final purification step was carried out by preparative polyacrylamide electrophoresis (12). The purified apolipoprotein A-II yielded a single band on polyacrylamide gel electrophoresis in sodium dodecyl sulphate (SDS) (12).

\section{Preparation of apolipoprotein $A=I I$ antisera}

Rabbits were immunized at multiple intradermal sites with $1 \mathrm{mig}$ apolipoprotein A-II mixed with complete Freund's adjuvant. At intervals of 3 weeks, the animals received booster doses, consisting of half the dose of antigen and incomplete Freund's adjuvant. Animals were bled after $1 \dot{2}$ weeks. The antisera were monospecific as tested by double diffusion in agarose.

Preparation of the apolipoprotein A-II-enzyme conjugate

Apolipoprotein $\dot{A}-$ II was labelled with horseradish peroxidase according to the method of Nakane et al. (13). The apolipoprotein A-II-enzyme conjugate was isolated by passing through a $100 \times$ $2.5 \mathrm{~cm}$ column of Sephacryl S 200 . The first peak was collected and concentrated in an Amicon cell using a PM 10 filter. After addition of bovine albumin and merthiolate to a final concentration of $10 \mathrm{~g} / \mathrm{l}$ and $0.1 \mathrm{~g} / \mathrm{l}$ respectively, the apolipoprotein A-IIenzyme conjugate was stored at $4^{\circ} \mathrm{C}$.

\section{Standards}

Dilutions of a serum pool in phosphate buffered salin̄ê/Tween containing $10 \mathrm{~g} / \mathrm{l}$ bovine serum albumin and $0.1 \mathrm{~g} / \mathrm{l}$ merthiolate were used as apolipoprotein A-II standards.

To determine the apolipoprotein A-II content of the serum pool, $\mathrm{HDL}(1.063<\mathrm{d}<1.21 \mathrm{~g} / \mathrm{l})$ was isolated by sequential ultracentrifugation (14) and its apoprotein content measured by the method of Lowry (15), using bovine serum albumin as a standard; the apolipoprotein A-III contribution to the HDL protein was as= sumed to be approximately $0.20(5,6,9,10)$.

\section{Enzyme immunoassay procedure}

The typical enzyme immunoassay was carried out in the following way. Each well of a microtitre plate was filled with 0.1 mil of a solution of $50 \mathrm{mg}$ / l anti-apolipoprotein A-III İG in carbonate-hydrogencarbonate buffer pH 9.6. IgG had been isolated previously from the anti-apolipoprotein A-II-antiserum by ammonium sulphate precipitation and DEAE-Trisacryl chromatography. The microtitre plates were covered with parafilm and incubated for 3 hours at $37^{\circ} \mathrm{C}$. The contents of the plates were then aspirated and dried in an air stream at room temperature for approximately 15 minutes, then washed 7 times with phosphate buffered saline/ Tween. The plate filled with phosphate buffered saline/Tween was then incubated for approximately 10 minutes at $37^{\circ} \mathrm{C}$ to enhance the desorption of all IgG not strongly fixed to the walls of the plate wells. Finally the plate was washed again 3 times with phosphate buffered saline/Tween. Standard or serum was diluted $1: 1000$ with phosphate buffered saline/Tween containing $10 \mathrm{~g} / \mathrm{l}$ bovine serum albụmin and $0.1 \mathrm{~g} / \mathrm{l}$ merthiolate. Apolipoprôtein $\mathrm{A}$ II-enżyme conjugate was diluted 1:50 with phosphate buffered saline/Tween containing $10 \mathrm{~g} / \mathrm{A}$ bovine serum albumin. $50 \mu \mathrm{l}$ dilutted standard or serum were mixed with $50 \mu$ diluted apolipoprotein A-II-enzyyme conjugate and added in duplicate to each well of a coated microtitre plate, with the exception of the wells belonging to the external rows of the plate, which were left free. The 
covered plates were incubated for 4 hours at $30^{\circ} \mathrm{C}$. The contents were then aspirated and the plates were washed 7 times with phosphate buffered saline/Tween. $0.1 \mathrm{ml}$ of chromogen solution was pipetted into each well and the plate was left at room temperature in the dark. After 30 minutes, $0.1 \mathrm{ml}$ of $250 \mathrm{~g} / \mathrm{kg}$ hydrochloric acid was added to each well and the absorbance was measured within 30 minutes at $492 \mathrm{~nm}$. As a blank $0.1 \mathrm{ml}$ unreacted chromogen solution with $0.1 \mathrm{ml} 250 \mathrm{~g} / \mathrm{kg}$ hydrochloric acid was used.

The results were expressed as a fraction of the absorbance at $492 \mathrm{~nm}$ when no competing antigen was present (i.e. $\mathrm{B} / \mathrm{B}_{0}$ ).

B: absorbance in the presence of standard, or unknown sample.

$\mathrm{B}_{0}$ : absorbance in the absence of standard or unknown sample. Results were calculated using the logit transformation: logit $B / B_{0}$ $=\ln B / B_{0}:\left(1-B / B_{0}\right)$. Standard curves were plotted using $y=\log$ $B / B_{0}$ or $y=B / B_{0}$ and $x=\log$ dose standard in nanogram.

\section{Treatment of the samples}

Some serum samples were delipidated with ethanol-ether (11) and some serum samples were fractionated by sequential ultracentrifugation in order to isolate very low density lipoproteins (VLDL) (d $<1.006 \mathrm{~kg} / \mathrm{l})$, low density lipoproteins (LDL) $(1.006<\mathrm{d}<1.063$ $\mathrm{kg} / \mathrm{l})$ and $\mathrm{HDL}(1.063<\mathrm{d}<1.21 \mathrm{~kg} / \mathrm{l}(14)$.

\section{Results}

\section{Optimizing assay conditions}

Effect of different amounts of anti apolipoprotein A-II IgG to coat the microtitre plate wells

$0.1 \mathrm{ml}$ of anti apolipoprotein A-II IgG in different amounts between 20 and $100 \mathrm{mg} / \mathrm{l}$ diluted in carbonate-hydrogen carbonate buffer was dispensed into the wells of a microtitre plate and incubated for 3 hours at $37^{\circ} \mathrm{C}$. After washing, the plates were used as in the typical enzyme immunoassay procedure. The results are shown in figure 1.

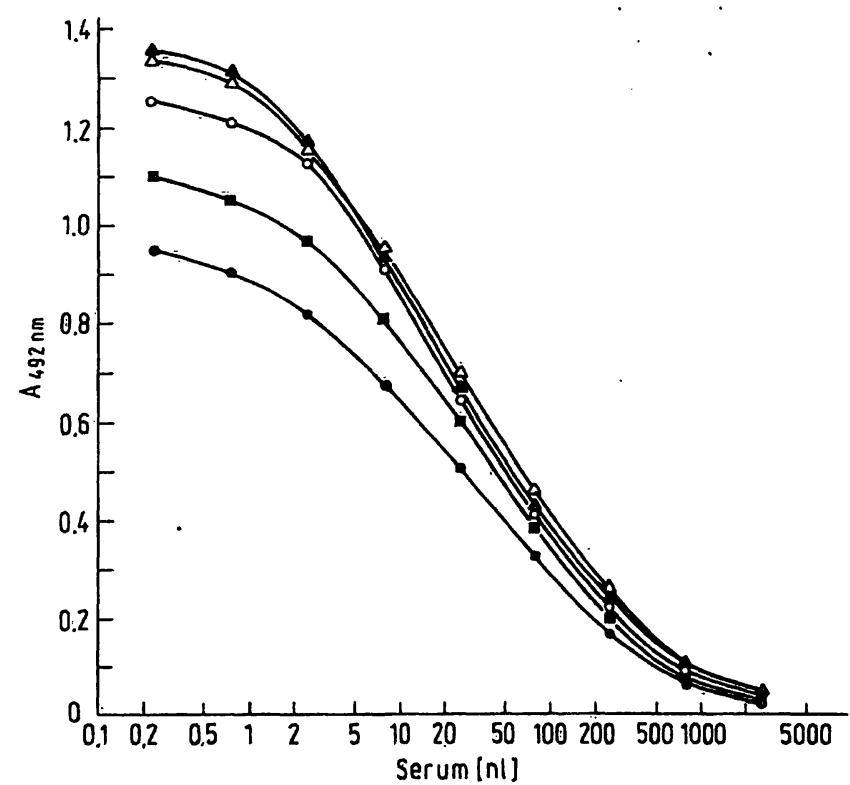

Fig. 1. Effect on the standard curves of different amounts of anti apolipoprotein A-II IgG used to coat the microtitre plate wells (O- $20 \mathrm{mg} / \mathrm{l}, 0-0: 40 \mathrm{mg} / \mathrm{l}, \Delta-\Delta: 60 \mathrm{mg} / \mathrm{l}$, $\Delta-\Delta: 80 \mathrm{mg} / \mathrm{l}, \mathbf{m}: 100 \mathrm{mg} / \mathrm{l})$.
Effect of different dilutions of apolipoprotein A-II-enzyme conjugate

$50 \mu \mathrm{l}$ of apolipoprotein A-II-enzyme conjugate diluted between $1 / 33$ and $1 / 400$ were added to $50 \mu$ l of a series of standards and the mixture was dispensed into coated microtitre plate wells. The typical enzyme immunoassay procedure was then followed. The results are shown in figure 2 .

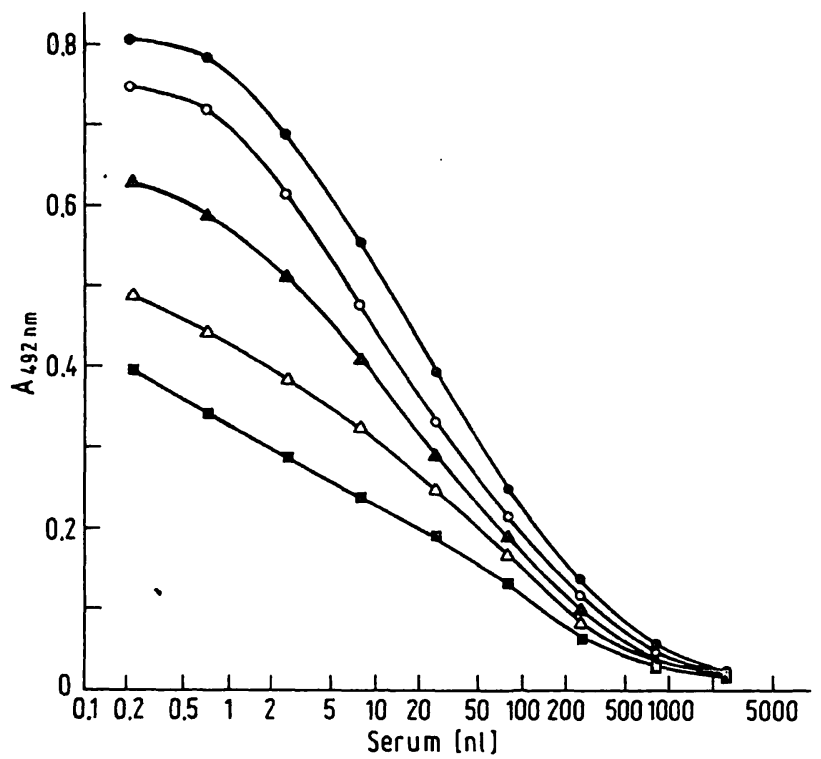

Fig. 2. Effect of various dilutions of apolipoprotein A-II-enzyme conjugate on the standard curves (O-O: 1:33, $\mathrm{O}-\mathrm{O}$ : $1: 50, \Delta-\Delta: 1: 100, \Delta-\Delta: 1: 200, \mathbf{\square}-\mathbf{D}: 1: 400)$.

Coating of the plates with $50 \mathrm{mg} / \mathrm{l}$ anti-apolipoprotein A-II IgG, and a dilution of $1 / 50$ for apolipoprotein A-II-enzyme conjugate were selected as optimal for economy, precision and displacement of labelled apolipoprotein A-II.

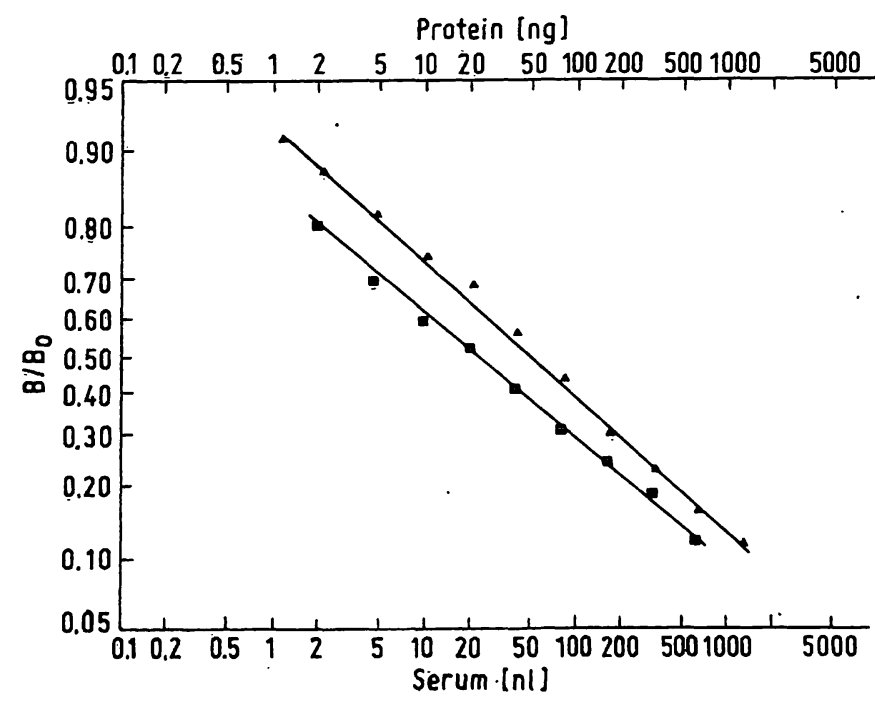

Fig. 3. Logit-log plot of the displacement curves of purified apolipoprotein A-II $(\mathbf{B}-\mathbf{a})$ and serum $(\boldsymbol{\Delta}-\mathbf{\Delta})$. 
Parallelism between serum and purified apolipoprotein A-II

When the results were fitted in a logit-log plot, there was a good parallelism between serum and purified apolipoprotein A-II suggesting immunological identity (fig. 3). However, on several occasions serum demonstrated a slighty greater ability to displace the enzyme labelled apolipoprotein A-II than purified apolipoprotein A-II.

\section{Effect of delipidation}

Delipidation of serum with ethanol-ether caused practically no alteration in the apparent content of apolipoprotein A-II (tab. 1).

Tab. 1. Effect of serum delipidation on the concentration of apolipoprotein A-II.

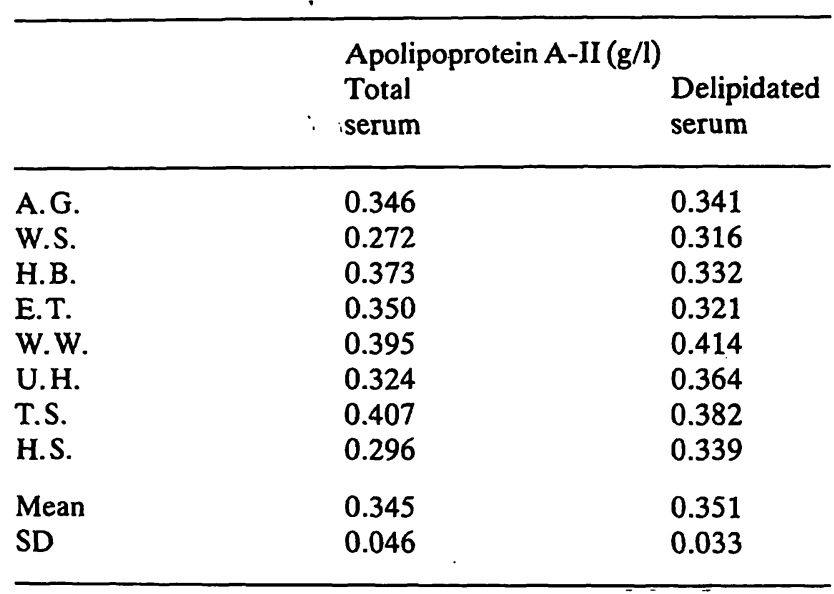

\section{Specificity}

The cross-reactivity with purified apolipoprotein A-I was about $1 \%$. As demonstrated by the displacement produced by isolated LDL. and VLDL, the crossreactivity with these lipoprotein fractions was only minimal in the working range of the assay (fig. 4).

\section{Precision}

To assess the precision of the assay, 3 serum pools containing high, medium and low amounts of apolipoprotein A-II were used. The intra-assay coefficient of variation was estimated by 20 replicated analyses of apolipoprotein A-II in the three serum pools. The inter-assay coefficient of variation was estimated by making duplicate analyses in the 3 pools on 10 different days. The results are shown in tab. 2 .

\section{Discussion}

Numerous studies have yielded conflicting results concerning the normal values of apolipoprotein A-II in serum $(1-10)$. This may have been caused in part

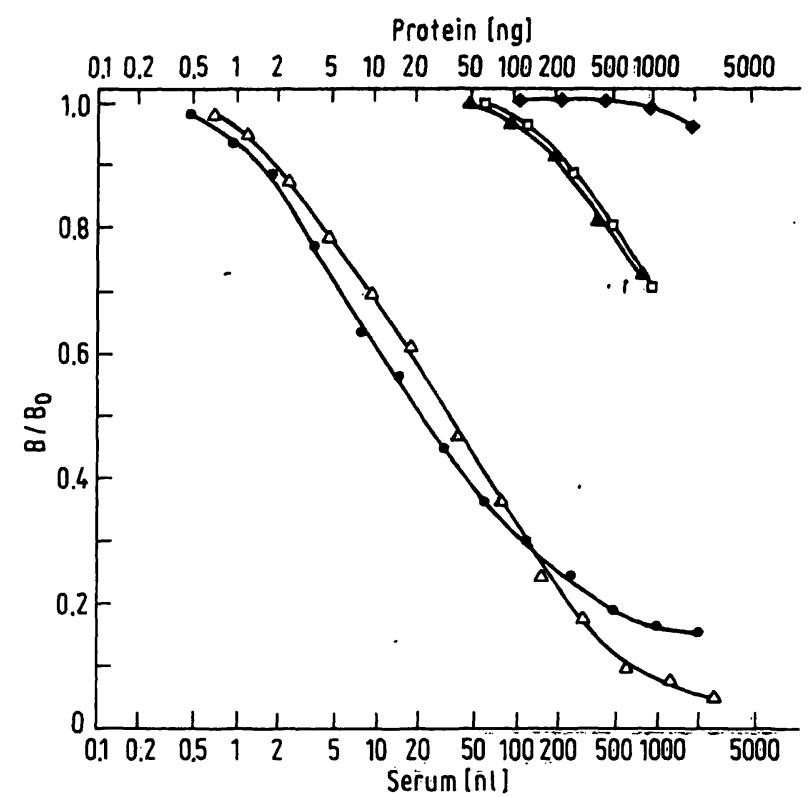

Fig. 4. Displacement curves of àpolipoprotein A-II-enzyme conjugate by whole serum $(\triangle-\Delta)$, HDL (d: $1.063-1.21 \mathrm{~kg}$ ) l) $(\odot-0)$, VLDL $(\mathrm{d} \leqslant 1.006 \mathrm{~kg} / \mathrm{l})(\mathbf{\Delta}-\mathbf{\Delta}), \operatorname{LDL}(\mathrm{d}: 1.006$ $-1.063 \mathrm{~kg} / \mathrm{l})(->)$ and purified apolipoprotein A-I $(\square-\square)$. Protein concentrations were determined by the method of Lowry (15).

Tab. 2. Intra- and inter-assay precision (serum pool)

\begin{tabular}{|c|c|c|c|}
\hline Intra-assay precision & $\begin{array}{l}\text { Apoli } \\
\text { (g/l) } \\
\text { Mean }\end{array}$ & $\begin{array}{l}\text { ein A-II } \\
\text { SD }\end{array}$ & $\begin{array}{l}\text { CV } \\
(\%)\end{array}$ \\
\hline \multicolumn{4}{|l|}{ High concentration of } \\
\hline $\begin{array}{l}\text { Medium concentration of } \\
\text { apolipoprotein } A-I I\end{array}$ & 0.344 & 0.031 & 9.0 \\
\hline $\begin{array}{l}\text { Low concentration of } \\
\text { apolipoprotein A-II }\end{array}$ & 0.204 & 0.017 & 8.5 \\
\hline \multicolumn{4}{|l|}{ Inter-assay precision } \\
\hline $\begin{array}{l}\text { High concentration of } \\
\text { apolipoprotein A-II }\end{array}$ & 0.413 & 0.06 & 14.6 \\
\hline $\begin{array}{l}\text { Medium concentration of } \\
\text { apolipoprotein A-II }\end{array}$ & 0.351 & 0.041 & 11.8 \\
\hline $\begin{array}{l}\text { Low concentration of } \\
\text { apolipoprotein A-II }\end{array}$ & 0.228 & 0.029 & 12.6 \\
\hline
\end{tabular}

by differences in the molecular form of apolipoprotein A-II between the standards and the test samples. These discrepancies stress our present difficulties in finding a suitable apolipoprotein A-II stañdard. Goldberg et al. (6) used purified apolipoprotein A-II as a standard in their radioimmunoassay of apolipo= protein A-II. It is well known that, in aqueous solution, purified apoproteins have a tendency to aggregate and this may cause a change of their immunological characteristics.

In our assay, we preferred to use as a standard whole serum whose apolipoprotein A-II content had been estimated with a reasonable approximation. The apolipoprotein A-II mass of HDL hạs gènerally been 
found to represent 0.20 of the total apoprotein $(5,6$, $9,10)$, and interestingly in all forms of hyperlipidaemia the proportion of apolipoprotein A-II in HDL was found to be unaltered (16).

In their radioimmunoassay for apolipoprotein A-II, Goldberg et al. (6) found that in a logit-log plot, serum dilutions produced displacement curves that were not parallel to those of purified apolipoprotein A-Il and they observed a more effective displacement of iodinated apolipoprotein A-II by increasing doses of purified apolipoprotein A-II than by whole serum. Karlin et al. (17) also pointed out the nonparallelism between dilutions of $\mathrm{HDL}$ and purified apolipoprotein A-II, but noted a less effective displacement by purified HDL apolipoproteins than by HDL. In general we observed in our assay an acceptable parallelism between purified apolipoprotein A-II and diluted serum. Nevertheless, as mentioned previously, we preferred to use dilutions of a serum pool as standards.

It has been reported several times that in contrast to apolipoprotein A-I, delipidation of serum did virtually not appear to expose additional antigenic determinants of apolipoprotein A-II $(5,7,9)$. Our results of delipidation confirmed this and made a delipidation step of the serum samples before assay unnecessary.

The sensitivity of our single antibody method using specific anti-apolipoprotein A-II IgG bound to a solid phase, was relatively low compared with the sensitivity of a double antibody radioimmunoassay described previously (5). This feature of the assay, however, made it possible to avoid the very high dilutions of the

\section{References}

1. Albers, J. J., Wahl, P. W., Cabana, V. G., Hazzard, W. R \& Hoover, J. J. (1976) Metabolism 25, 633-644.

2. Cheung, M. C. \& Albers, J. J. (1977) J. Clin. Invest. 60, 43-50.

3. Norum, K. R., Glomset, J. A., Nichols, A. V., Forte, T., Albers, J. J., King, W. C., Mitchell, C. D., Applegate, K. R., Gong, E. L., Cabana, V. G. \& Gjone, E. (1975) Scand. J. Clin. Lab. Invest. 35, (suppl. 142), 31-45.

4. Curry, M. D., Gustafson, A., Alaupovic, P. \& McConathy, W. J. (1978) Clin. Chem. 24, 280-286.

5. Assmann, G., Smootz, E., Adler, K., Capurso, A. \& Oette, J. (1977) J. Clin. Invest. 59, 565-575.

6. Goldberg, R. B., Karlin, J. B., Juhn, D. J., Scanu, A. M., Edelstein, C. \& Rubenstein, A. H. (1980) J. Lipid Res. 21, 902-912.

7. Mao, S. J. T., Gotto, A. M. \& Jackson, R. L. (1975) Biochemistry $14,4125-4131$.

8. Riesen, W. F. \& Middelhoff, G. W. (1978) FEBS Letters 91, 35-39.

9. Schonfeld, G. J., Chen, J., McDonell, W. F. \& Jeng, I. (1977) J. Lipid Res. 18, 645-655.

10. Shepard, J., Packard, J. C., Patsch, J. R., Gotto, A. M. \& Tauton, O. D. (1978) Eur. J. Clin. Invest. 8, 115-120. serum samples which were necessary in the radioimmunoassay.

For optimal precision of the assay, the following methodical details were important. First, because of their variation in protein adsorption $(18,19)$ the external rows of the microtitre plate were not used. Second, coating of the plate with excessive amounts of anti-apolipoprotein A-II IgG was avoided since this resulted in a loss of precision. Third, the plates were coated with no more than $0.1 \mathrm{ml}$ of IgG solution in carbonate-hydrogen carbonate buffer and the total volume of sample plus apolipoprotein-enzyme conjugate amounted also to $0.1 \mathrm{ml}$. This ensured that no labelled or unlabelled apolipoprotein A-II became bound to antibody fixed at the upper part of the well during the washing procedure. Fourth, the plate was coated at $37^{\circ} \mathrm{C}$, then dried in an air stream and during the washing procedure incubated at $37^{\circ} \mathrm{C}$. During the incubation with standard or sample and apolipoprotein-enzyme conjugate, however, the temperature was limited to $30^{\circ} \mathrm{C}$. This caused a net improvement of the precision, probably by reducing the desorption of anti-apolipoprotein A-II IgG from the plates during the incubation with sample and apolipoprotein-enzyme conjugate.

In order to appreciate the predictive ability of apolipoproteins in the evaluation of the risk of coronary heart disease, simple, fast, reliable and precise methods for the assay of apolipoproteins are required. The enzyme immunoassay is characterised by minimal demands on equipment and technical expertise and may be adapted for the quantification of apolipoprotein A-II in clinical routine. The preparation of a suitable standard, however, deserves further studies.

11. Scanu, A., Toth, J., Edelstein, D., Koga, S. \& Stiller, E. (1969) Biochemistry 8, 3309-3316.

12. Neville, D. M. (1971) J. Biol. Chem. 246, 6328-6334.

13. Nakane, P. K. \& Kawaoi, A. (1974) J. Histochem. Cytochem. 22, 1084-1091.

14. Havel, R. J., Eder, H. A. \& Bragdon, J. H. (1955) J. Clin. Invest. 34, 1345-1354.

15. Lowry, O. H., Rosebrough, N. J., Farr, A. L. \& Randall, R. J. (1951) J. Biol. Chem. 193, 265-275.

16. Schonfeld, G. J., Bailey, A. \& Steelman, R. (1978) Lipids 13, 951-959.

17. Karlin, J. B. \& Rubenstein, A. H. (1979) In: Biochemistry of Atherosclerosis (Scanu, A. M. ed.) Marcel Dekker Inc., New York, pp. 189-225.

18. Burt, S. M., Carter, T. J. N. \& Kricka, L. J. (1979) J. Immunol. Methods 31, 231-236.

19. Kricka, L. J., Carter, T. J. N., Burt, S. M., Kennedy, J. H., Holder, R. L., Halliday, M. J., Telford, M. E. \& Wisdom, G. B. (1980) Clin. Chem. 26, 741-744.

Dr. B. Dufaux

Institut für Kreislaufforschung und Sportmedizin der Deutschen Sporthochschule Köln

Carl-Diem-Weg

J. Clin. Chem. Clin. Biochem. / Vol. 21, 1983 / No. 1 
. 